\title{
1979 Food and Agricultural Outlook
}

\author{
NEIL A. STEVENS and CLIFTON B. LUTTRELL
}

翼

HE 1979 forecast of U.S. food and agricultural developments by the U.S. Department of Agriculture (USDA) points to larger food supplies and a slower rate of food price increases than last year. Net farm income is expected to be above the relatively high 1978 level. These general conclusions by USDA anam lysts will be discussed in this article along with a brief review of food and agricultural developments in 1978.

\section{8 in Review}

In 1978 food prices increased at a rapid 10 percent rate, well above the 4 to 6 percent rate of increase that the USDA had predicted in late 1977. The USDA based its outlook predictions on expectations of a moderate increase in demand and larger beginning stocks of grain and other feedstuffs. The underestimation of food price inflation in 1978 resulted, in part, from a greater-than-expected increase in the demand for food, reflecting an unanticipated increase in total aggregate demand in the U.S. economy which was fueled by rapid advances in the nation's money stock. Most economic forecasters underestimated the rise in aggregate demand and, as a result, underpredicted the nation's inflation rate.

Unexpected food supply developments resulted in additional upward pressure on food prices in 1978 . Beef production was down about 4 percent, as anticipated. But, for the second successive year, severe weather adversely affected the quantity of pork produced. Although farrowings had been expected to rise by 13 percent over their 1977 level, they actually declined 1 percent during the severe winter months. Consequently, hog production rose only 1 percent for the year rather than the anticipated 10 percent. Since the increases in hog and poultry production did not materialize and offset the price impact of the decline in beef production, meat prices rose sharply from their 1977 levels. Furthermore, bad weather in the early months of the year contributed to reduced vegetable production, which caused a sharp rise in vegetable prices early in 1978. Finally, changes in the method of calculating the consumer price index

1U.S., Congress, Senate; Committee on Agriculture, Nutrition, and Forestry; 1979 Food and Agricultural Outlook, NinetyFifth Congress, Second Session, December 29, 1978; and subsequent outlook releases of the United States Department of Agriculture. had a marginal upward impact on the reported rate of increase in food prices. Higher weights in the index were given to such categories as food away from home and non-alcoholic beverages which tended to increase measured food prices.

\section{LARGER INVENTORIES OF COMMODITIES AVALABLE FOR FOOD PRODUCTION}

Despite the recent weather-related decline in food supplies, particularly fresh vegetables and livestock, the food supply situation is improved in 1979 from a year ago. An expanded base of farm commodities, including feed grain, oilseed, and livestock and poultry with the exception of cattle, is available for food production.

\section{Feed Grains}

Record world feed grain production is expected in $1978-79$, up about 6 percent from the previous year's crop. Last fall, U.S. production of feed grains contributed to this increase, with a record output of about 217 million tons in 1978-79, up 7 percent from the relatively large $1977-78$ harvest. This large U.S. harvest in 1978-79 resulted from an 11 percent in crease in yields which more than offset the 4 percent decline in acres harvested. Com, the major U.S. feed grain crop, contributed most to the larger output as several com-producing states experienced nearly ideal weather conditions. The average com yield for 1978-79 is estimated at 101 bushels per acre, up 11 bushels per acre from the 1977-78 average.

As a result of the large harvest of feed grains last fall, the total supply in the United States for the current year is 259 million tons, up from 234 million tons last year, and 211 million tons in 1976-77.

\section{Food Grains}

World wheat production is estimated at an all-time high in the 1978-79 crop year, up about 14 percent from 1977-78. Production in the United States, however, was down about 12 percent from $1977-78$ as a result of Government programs which reduced the acreage planted to wheat, and adverse planting conditions in some wheat-growing areas. Since almost 
1.2 billion bushels of wheat were held in the United States at the beginning of the current marketing year, the total supply available for domestic consumption plus exports is 2.98 billion bushels, only 5.5 percent below the relatively large 1977-78 supply.

Higher prices provided farmers with the incentive to produce a record U.S. rice crop last year. Acreage harvested was up 36 percent from 1977 and average yields were up 2 percent; hence, production was up sharply, rising from 99 million hundredweight (cwt.) in 1977 to 138 million cwt. last year. Carryover stocks totaling 27.4 million cwt. at the beginning of the current marketing year were down from the 40.5 million cwt. a year ago. Nevertheless, the total supply of 165 million cwt. this year is well above the estimated 140 million ewt. in 1977-78.

\section{Oilseeds}

The U.S. soybean crop was at a record 1.8 billion bushels in 1978. This was 5 percent above the relatively large crop in 1977 . Nearly 10 percent more acres were harvested than a year earlier, but average yields were down 1.4 bushels per acre from record high yields of 1977. With beginning stocks at 161 million bushels, up somewhat from a year ago, total supplies are estimated at about 2 billion bushels. This is about 7 percent more than last year.

U.S. cotton production in 1978 was 10.8 million bales, down a hefty 25 percent from the previous year. Relatively low prices in early 1978 induced a 5 percent decline in acreage planted. Also, adverse growing conditions - especially in Texas, Oklahoma, and California - resulted in a 19 percent decline in yields from the above-average yields in 1977. This lower production, combined with the large beginning stocks, provided a total supply of 16.2 million bales in 1978-79, only 6 percent below the 1977-78 level. With the larger carryover stocks, however, cottonseed supplies in the current marketing year are estimated at 5 million short tons, only about 13 percent below last year.

\section{Livestock Herds and Flocks}

One of the less favorable food outlook factors is the declining inventory of cattle. The January 1 , 1979 , inventory of cattle and calves on farms was 110.9 million head, down 16 percent from its peak in 1975. The smaller cow herd suggests that the 1979 calf crop will be down somewhat from the estimated 44.1 million last year. The number of cattle in feedlots early this year was slightly smaller than a year ago. Furthermore, the number placed in feedlots during the fourth quarter of 1978 was down about 9 percent from a year ago, and, if the anticipated herd rebuilding begins, more heifers will be kept for breeding purposes, and the placements in feedlots will continue at a lower rate during 1979.

The hog and pig inventory is more likely to pro. vide greater production than the cattle inventory. The number of hogs and pigs on farms has been rising since 1975, and the number kept for breeding purposes last December was 11 percent greater than a year earlier and 19 percent greater than on December 1, 1976. Sufficient breeding hogs are available for a sharp increase in farrowings. Farrowings in September-November 1978, for example, were 10 percent above a year earlier, and estimates of farrowings this spring are up 16 percent from last year's level.

The number of milk cattle on farms has decreased in recent decades, declining from an average of 21.0 million head in early 1955 to 10.9 million in late 1978. Last year's decline, however, was quite small.

Inventories of laying hens for commercial egg production this year are about the same as a year ago. Layers for broiler-hatching eggs, however, are more plentiful than last year. Placements of pullets last fall indicate that the broiler-hatchery flock will be about 14 percent larger in the first quarter of this year than a year ago.

\section{FORECAST OF 1979 FOOD OUTPUT}

Given the existing supply of basic food commodities and livestock, USDA analysts project larger food supplies this year than in 1978. As a result of the relatively large supply of feed and expectations of relatively stable feed prices, farmers and ranchers have an incentive to increase livestock feeding. The relatively small inventory of cattle will limit beef output despite the greater incentive for feeding, but pork and poultry production is expected to increase sharply. Production of red meat plus poultry is expected to increase at about the same rate as population growth; hence, per capita output will remain unchanged from 1978 levels.

\section{Livestock Products}

Beef production is expected to decline 6 percent this year following an estimated 4 percent decline last year. Again, this decline is expected to be in 
the lower-priced cuts. Slaughter of steers and heifers directly off the pasture, so-called nonfed beef, is expected to total only about one-half to two-thirds the 1978 level. Cow slaughter also will be down, perhaps as much as one-fifth from 1978. The production of higher-quality beef from feedlot cattle may be up slightly from the 1978 level.

In contrast to the projected decline in beef production, both pork and poultry production are expected to increase by about 10 percent. Hog producers are increasing sow farrowings sharply in response to the greater incentive for feeding. There will be 9 percent more hogs available for slaughter in the spring quarter, and the year-to-year increase is expected to widen in the summer and autumn quarters. Broiler and turkey producers experienced relatively high profits in 1978, and the outlook is again favorable for producers in 1979. As a result, broiler production may rise 8 to 10 percent above last year's level, and turkey production in the first half of 1979 is expected to increase 20 to 25 percent from year-ago levels.

The relatively low egg prices late last year were not sufficient to provide much incentive for increased production. Nevertheless, overall egg production is expected to rise slightly this year; but most, if not all, of the increase will go to hatcheries for broller chickens rather than to grocery stores. With population trending upward, egg consumption per person may continue downward. Per capita egg consumption declined from 40.7 pounds in 1967 to about 35 pounds last year.

Milk production for the first half of 1979 is expected to remain at the same level as a year ago, and to rise only slightly for the year as a whole.

\section{Crop Foods}

Crop-related food supplies, on the whole, will likely expand somewhat in 1979; thus, per capita consumption of crop foods should increase. Stpplies of most cereals (largely wheat and rice) are well above expected domestic consumption at Govemment price-support levels. Hence, the quantity of food output from cereal grains, given these prices, will be determined largely by constmer demand.

Prospects are that fruit supplies per capita will be slightly less this year than a year ago and that vegetable supplies will be about the same. The projected 1978-79 orange crop is even smaller than last year's weather-damaged crop, but juice yields should in- crease enough for the output of frozen concentrate to exceed last year's production by about 5 percent. The noncitrus fruit crop was slightly smaller than last year's crop.

The total stock of processed vegetables, both camned and frozen, on January 1, 1979, was about the same as last year. Carryover stocks of most canned vegetables into the 1978.79 marketing year were lower than a year earlier, and, with a slightly smaller pack of most items, the supply of canned vegetables in the 1978-79 marketing year is slightly lower than in the previous year. On the other hand, January 1 stocks of frozen vegetables were 11 percent larger than a year ago. Potatoes also are relatively abundant; last fall's harvest exceeded the previous record harvest in 1976 by 1.5 percent.

Soybean oil supplies, which now account for about 60 percent of all U.S. fats and oils, are projected at 11.5 billion pounds, up about 5 percent from a year ago. Domestic use is expected to total around 8.7 billion pounds, 5 percent more than in 1977-78. Among other oils, greater quantities of sunflower seed, com, peanut, and imported palm oil should be available, but supplies of cottonseed oil and butter will be down.

\section{IMPLICATIONS FOR FOOD PRICES AND FARM INCOMES}

\section{Food Prices}

Despite expected gains in food production this year, USDA analysts forecast an 8.5 percent increase in food prices, about equal to the expected rate of inflation. This increase, if realized, would be well below the 10 percent increase in 1978 food prices.

Underlying the food price forecast for this year are specific assumptions about the likely behavior of the three major components of food expenditures the value of basic farm commodities, the value of marketing services, and expenditures for "other" foods (those without a domestic farm produot base, such as fish, coffee, bananas, and sugar). These three com" ponents account for roughly 26,57 , and 17 percent of total food expenditures, respectively. ${ }^{2}$ The value of farm commodities and the "other" foods are the

\footnotetext{
2Marketing services as used here indude transportation, storing, millng, slanghtering, processing, and all other functions which are included in the food production process from the time foodstuffs leave the farmer untel they reach the consumer.
} 
most volatile of these components since their production fluctuates with weather conditions. Last year, for instance, the reduced supplies of meat and vegetables had such a significant impact on domestic farm product prices that farm prices were a major contributor to the greater-than-expected increase in food prices. Prices of the "other" food category - fish, coffee, bananas, and sugar - have risen over 145 percent since 1970 compared with the 60 percent increase in prices of domestically-produced foods. Prices of marketing services, on the other hand, are more stable from year to year and closely follow the general rate of inflation.

Given the above weights for each of the food cost factors, the forecast of an 8.5 percent increase in food prices in 1979 is based on the expected price behavior in each component. The prices of all farm commodities, for example, are expected to increase about 10 percent in 1979 , since they account for about one-fourth of total food costs, they will contribute almost 2 percentage points to the overall food price increase.

The marketing cost component also is expected to rise about 8 percent this year, about equal to the rate of inflation. Marketing costs will contribute about 5 percentage points to the predicted food price increases. Finally, prices of "other" foods are expected to rise about 6 percent and contribute about 1 percentage point to the overall increase in food prices.

While most types of foods are expected to rise in cost over last year, some will rise at a faster rate than others. Hence, consumers will likely make further alterations in their diets by shifting to relatively lower-priced substitute foods. Most of the substitutions will likely take place within the meat categories. For example, with the increased output of high-quality beef (especially early in the year) and of pork and poultry, prices of these meats will decline relative to hamburger and other lowerquality beef. Consequently, consumers will change their diets to include less hamburger and more of the other meats. Nevertheless, expanding demand based on somewhat higher consumer incomes, cou" pled with little change in per capita meat production, will result in higher average meat prices.

Retail meat prices are expected to average about 11 percent above last year's level, with the price of beef registering the largest price increase. Price increases in other red meats will be relatively small. Despite increased broiler and turkey production in prospect, poultry prices are likely to average more than 5 percent above the 1978 level. Broiler prices are expected to average somewhat above the 1978 level. Turkey prices should average above the prices of a year earlier in the first half of the year and below the prices of a year earlier in the second half.

With a downtrend in the demand for eggs in recent decades, 1979 prices are likely to rise more slowly than the general rate of inflation despite the relatively stable level of egg production. Milk prices and retail prices for other dairy products are likely to rise about 8 percent from their 1978 level, and per capita consumption of these products is expected to increase only marginally.

Despite the abundant supplies of the cereal crops, wheat and rice, prices of food derived from these commodities are expected to increase at or slightly above the general rate of inflation. Part of this increase can be attributed to Government price supports of grain through the grain reserve program, part to the sharp increase in exports, and part to rising processing and marketing costs.

Demand for processed vegetables should continue to increase, and prices are likely to rise as fast as the overall rate of inflation. Also, coupled with strong demand, overall prices of canned and frozen fruit products are expected to rise significantly in 1979 and average about 10 percent above 1978.

\section{Onlook for Tann Income}

Economic conditions for farmers improved in 1978. Last year's net farm income of $\$ 28.1$ billion was about 40 percent above that in 1977. This increase, due primarily to higher crop and livestock prices, was largely unanticipated at the 1977 USDA Agricultural Outlook Conference. At that time, farm income was expected to remain near the fairly low level of 1977 . Crop prices, for example, had been expected to average somewhat lower than the previous year, when, in fact, they rose by 6 percent above those for 1977 . In addition, only a small increase in overall livestock prices was anticipated, yet livestock prices in 1978 averaged 23 percent above their 1977 level.

Prospects are generally favorable for the improved 1978 farm income level to be increased in 1979. Cash receipts are largely dependent on 1979 crop and livestock production and prices. Since the quantity of feed and livestock inventories on hand are 
major factors in determining the supply of many farm products until late 1979 , and consumer income plus exports are major factors in determining demand, some predictions about prospective price movements can be made. These predictions by USDA analysts, as described in the previous sections, indicate average agricultural product price increases of about 10 percent in 1979. Most of the price increases are likely to occur among livestock products; there is little basis to expect much change in either average prices or production of crops.

Farm production expenses also are expected to rise over the whole range of farm inputs, including wages, nonfarm inputs, transportation, taxes, insurance, and interest. These increases will not offset the increases in overall cash receipts so that, on balance, net farm income may be above last year's level.

Tending to stabilize domestic crop prices, especially grain, is the improved world grain supply situation. Last year's world grain production - wheat, feed grains, and rice - is estimated to have increased 6.5 percent over output in 1977. This large harvest is expected to exceed consumption at current grain prices so that world stocks may reach 238 million tons - the highest level ever recorded - by the end of the current marketing year. Such stocks are equal to about 16 percent of world consumption this year, compared to the low of 11 percent in the mid-1970s. As a result of these increased stocks, sharp increases in grain prices are not likely in the first half of 1979 .

Utilization of U.S. feed grains is expected to increase about 5 percent in the current marketing year. Nevertheless, carryover stocks at the end of the year are expected to increase to almost 57 million tons, up sharply from 41 million tons at the end of last year. Such large stocks should preclude a sharp runup in prices as occurred in 1977-78. Part of these stocks have been removed from the market by the farmer-owned reserves which are expected to total about 22 million tons. These stocks are not to be marketed until corn prices to farmers reach at least $\$ 2.50$ a bushel. The grain storage program, expectations of continued heavy export demand, increased feeding use, and reduced feed grain acreage in 1979 as a result of the feed grain program are likely to keep com prices from declining during the 1978-79 marketing year. Corn prices should average between $\$ 2.05$ and $\$ 2.15$ a bushel for the $1978-79$ season, slightly above the previous year's average.

Large supplies likewise dominate the outlook for food grain producers. Beginning stocks of wheat totaled 1.2 billion bushels which, added to projected production of 1.8 billion bushels, provides a total supply of 3.0 billion bushels. This is 1.0 billion bushels in excess of total usage in 1977-78. Export demand for U.S. wheat has been quite strong so far this marketing year, reflecting primarily increased purchases by the People's Republic of China and Brazil. By the end of the year, large exports and the smaller U.S. crop are expected to have reduced the U.S. carryover of wheat stocks for the first time in four years. Projected year-end stocks of U.S. wheat will remain at 51 percent of projected use this year, down from the 60 percent in 1977 , but above the 20 to 25 percent levels of 1973 and 1974. World wheat stocks, however, are expected to be nearly 106 million tons, up about 24 million tons from 1977-78.

Despite the relatively large stocks of wheat, prices to farmers early this year were about 50 cents per bushel above a year ago and only about 25 to 30 cents per bushel below the $\$ 3.29$ release price of wheat in the price support (grain reserve) program. Little further increase in wheat prices is anticipated. A Government wheat program has been announced for 1979-80 that is similar to the 1978-79 program. It provides for acreage reduction, a target price, and a loan on wheat. The "set aside" stays at 20 percent.

The larger rice crops here and in a number of other major producing nations and the probability that rice exports will decline about 9 percent from a year ago have resulted in lower prices. U.S. rice prices for the 1978-79 marketing year are expected to average between $\$ 7.50$ and $\$ 7.80$ per cwt., down from about $\$ 9.50$ per cwt. last season. As a consequence of the larger rice supplies and the price support program, Government-held stocks will build up during the current marketing year.

Demand for the products derived from soybeans, chiefly oil and meal, continues to rise, and farm prices of soybeans early last year were almost $\$ 1.00$ per bushel above the previous year despite the larger crop in 1978. This rising demand for soybeans mainly reflects the prospective increase in demand for soybean meal used in feeding livestock and for exporting. Soybean exports in 1978-79 are projected at 760 million bushels - about 40 percent of the crop produced and 9 percent higher than the 1977-78 exports. USDA analysts estimate that year-end inventories of U.S. soybeans will approximate those at the beginning of the current marketing year.

Demand for cotton is expected to increase in 1979 and as the world cotton supply-demand situation has tightened, cotton prices have risen. For example, the U.S. average farm price for all types of cotton 
was about 57 cents per pound in early 1979 , about 9 cents per pound above a year earlier. Reflecting the reduced crop last fall and about the same level of domestic mill use plus exports, stocks of cotton are expected to be down to 4.1 million bales by the end of this marketing year compared with 5.3 million bales a year earlier.

Production of tobacco, a large cash crop in some areas of the United States, was 5 percent larger in 1978 than in the previous year, which reflects primarlly higher yields. Tobacco stocks are generally above desired levels despite acreage restrictions.

Tobacco use in the current marketing year is expected to remain near last season's level as the downward trend in domestic use offsets greater export demand. Use of U.S. produced tobacco in the current year will probably be less than the 1978 crop so that carryover this summer will likely be at higher levels than a year earlier. A smaller tobacco crop in 1979 is likely, however, as the USDA has reduced the 1979 marketing quotas for flue-cured tobacoo.

Since price supports are mandatory for tobacco produced inder marketing quotas, farm prices will rise in 1979 despite larger stocks of tobacco. According to the support formula, the price for the 1979 crop will rise about 7 percent from the 1978 average.

\section{SUMMARY}

According to USDA analysts, total food production will be somewhat greater this year than in 1978, but about the same per capita. Production of foods derived from livestock is expected to rise somewhat, with increases in pork, poultry, and milk offsetting declines in beef and eggs. Crop-related foods, on the whole, are also expected to expand. Food prices, however, are expected to rise about 8.5 percent, as a result of rising overall demand.

The projections for rising food production are based on the larger supplifs of feed available compared to a year ago and the greater incentive for feeding livestock and poultry. Feed grain supplies in the United States this year are almost 11 percent greater than a year ago, and prices of feed grain have not risen as much in the past 12 months as prices of livestock products.

Farm incomes should increase from 1978 levels. Farm commodity prices are expected to average about 10 percent higher than in 1978 with most of the increase contributed by higher prices for livestock products. Expected higher costs for farm inputs, however, will offset part of the gross fam income gains from the higher prices. 